\section{Do the salivary glands of patients with systemic sclerosis show ultrasonographic modifications suggestive of Sjögren's syndrome?}

The paper by Ferdowsi et al, reported a 23-item composite damage index to quantify organ damage in systemic sclerosis (SSc). ${ }^{1}$ In this index, sicca symptoms (item 3) play an important

\begin{tabular}{|c|c|c|c|}
\hline Characteristics & $\operatorname{SSc}(n=25)$ & $\mathrm{pSS}(\mathrm{n}=48)$ & Controls $(n=35)$ \\
\hline Age, years, mean $\pm S D$ & $64.8 \pm 9.5$ & $62.1 \pm 12.4$ & $55 \pm 15$ \\
\hline Female, $n(\%)$ & $22(88)$ & $46(95)$ & $34(97)$ \\
\hline Disease duration, years & $10.6 \pm 11.3$ & $10.6 \pm 7.8$ & $6.5 \pm 6.3$ \\
\hline \multicolumn{4}{|l|}{ Treatments } \\
\hline $\begin{array}{l}\text { Immunosuppressive } \\
\text { therapy, } \mathrm{n}(\%)\end{array}$ & $7(28)$ & $4(8.3)$ & $2(5.7)$ \\
\hline Hydroxychloroquine, n (\%) & $2(8)$ & $12(25)$ & $4(11.4)$ \\
\hline Glucocorticoids, n (\%) & $5(20)$ & $5(10.4)$ & $2(5.9)$ \\
\hline \multicolumn{4}{|l|}{ Clinical signs } \\
\hline Xerostomia, n (\%) & $10(40)$ & $48(100)$ & 30 (85) \\
\hline Xerophthalmia, n (\%) & $9(36)$ & $43(89)$ & $29(82)$ \\
\hline $\begin{array}{l}\text { Clinical parotid } \\
\text { enlargement, } \mathrm{n}(\%)\end{array}$ & 0 & $3(6.4)$ & $2(5.7)$ \\
\hline $\begin{array}{l}\text { Raynaud phenomenon, } \\
\text { n (\%) }\end{array}$ & $25(100)$ & $6(12.5)$ & $5(14.3)$ \\
\hline $\begin{array}{l}\text { Inflammatory arthralgia, } \\
\mathrm{n}(\%)\end{array}$ & $14(56)$ & $11(22.9)$ & $30(85.7)$ \\
\hline \multicolumn{4}{|l|}{ Laboratory tests } \\
\hline $\begin{array}{l}\text { Schirmer's test } \leq 5 \mathrm{~mm} \text {, } \\
\mathrm{n}(\%)\end{array}$ & 9/17 (53) & $38 / 47$ (80.9) & $8 / 32(25)$ \\
\hline $\begin{array}{l}\text { Unstimulated salivary flow } \\
\leq 0.1 \mathrm{~mL} / \mathrm{min}, \mathrm{n}(\%)\end{array}$ & 8/17 (47.1) & $41 / 47(87.2)$ & 16/33 (49.5) \\
\hline $\mathrm{ANA} \geq 1 / 160, \mathrm{n}(\%)$ & $24(96)$ & $36(75)$ & $17(49)$ \\
\hline Anti-Ro 52/SSA, n (\%) & $4(16)$ & $24(50)$ & $2(5.7)$ \\
\hline Anti-Ro 60/SSA, n (\%) & $2(8)$ & $26(54)$ & 0 \\
\hline Anti-La/SSB, n (\%) & 0 & $14(29.2)$ & 0 \\
\hline Rheumatoid factor, n (\%) & $3 / 22(14)$ & $16 / 39(41)$ & $2 / 35(5.7)$ \\
\hline Antitopoisomerase, n (\%) & $10(40)$ & $1(2.1)$ & 0 \\
\hline $\mathrm{ACA}, \mathrm{n}(\%)$ & $9(36)$ & $3(6.3)$ & 0 \\
\hline $\begin{array}{l}\text { ESR, med (Q1-Q3), mm at } \\
\text { first hour }\end{array}$ & $16(11-21)$ & $11(6-28)$ & $8(5-14)$ \\
\hline CRP, mean (Q1-Q3), mg/L & $2.9(2.9-8)$ & $2.9(0.5-3.8)$ & $2.9(0-6.5)$ \\
\hline $\begin{array}{l}\text { Focus score } \geq 1 \text { (labial } \\
\text { salivary gland), } n(\%)\end{array}$ & & $41 / 46(89)$ & $3 / 27(11)$ \\
\hline \multicolumn{4}{|l|}{ SGUS features } \\
\hline $\begin{array}{l}\text { Parotid length, mean } \pm S D \text {, } \\
\mathrm{mm}\end{array}$ & $41.5 \pm 7.8$ & $42.5 \pm 6.5$ & $45.9 \pm 5.2$ \\
\hline $\begin{array}{l}\text { Parotid width, mean } \pm S D \text {, } \\
\text { mm }\end{array}$ & $37 \pm 5.8$ & $35.8 \pm 6.5$ & $39 \pm 5.9$ \\
\hline $\begin{array}{l}\text { Submandibular surface } \\
\text { area, mean } \pm S D, \mathrm{~cm}^{2}\end{array}$ & $2 \pm 0.8$ & $1.8 \pm 0.5$ & $2.2 \pm 0.7$ \\
\hline $\begin{array}{l}\text { Submandibular length, } \\
\text { mean } \pm S D, m m\end{array}$ & $26.7 \pm 5.8$ & $28.4 \pm 5.7$ & $30.1 \pm 4.3$ \\
\hline \multicolumn{4}{|l|}{ US grade max, n (\%) } \\
\hline 0 or 1 & $18(72)$ & $12(25)$ & 32 (91.4) \\
\hline$\geq 2$ & $7(28)$ & $36(75)$ & $3(8.6)$ \\
\hline
\end{tabular}

ACA, anticentromere antibody; ANA, antinuclear antibody; CRP, C reactive protein; ESR, erythrocyte sedimentation rate;SGUS, Salivary gland ultrasound; SSA, Sjögren's-Syndrome-related-antigen type A antibody; SSB, Sjögren's-syndromerelated-antigen type B antibody; SSc, systemic sclerosis;US, ultrasonography; pSS, primary Sjögren's syndrome. role (weight score $=3$ ). Actually, sicca symptoms are frequently reported by patients with SSc $(7.5 \%-68 \%)$ and could be due to a fibrosis process of the salivary glands (SGs). ${ }^{2-4}$ In recent years, ultrasonography (US) of the parotid and submandibular glands has been widely used for identifying SG modifications in patients with primary Sjögren's syndrome (pSS). In order to assess modifications in the SG echostructure in patients with SSc and compare them with those of patients with pSS or controls with sicca symptoms, we prospectively enrolled patients with SSc fulfilling the American College of Rheumatology/European League against Rheumatism (ACR/EULAR) 2013 classification criteria, patients with pSS according to the ACR/EULAR 2016 classification criteria, and controls with sicca symptoms. Bilateral parotid and submandibular ultrasound was performed on every patient by the same operator (MC) blinded to the diagnosis. The inhomogeneity of each of the four major SGs in B-mode was graded using the Cornec et al scoring system (scale of 0 to 4 ) as previously described. ${ }^{5}$ The highest grade among the four glands was suggestive of Sjögren's syndrome if $\geq 2$.

A total of 108 patients were included in the study: SSc $(n=25)$, pSS $(n=48)$ and controls $(n=35)$. The characteristics of the patients are shown in table 1. When comparing the pSS and controls, the performance of an US echostructure grade $\geq 2$ for the diagnosis of pSS was good (sensitivity: $75 \%$, specificity: $91.4 \%$, positive predictive value: $92.3 \%$, negative predictive value: $72.7 \%$ ). Among the 25 patients with SSc, 9 had a history of or had a current digital ulcer, 8 had interstitial lung disease, 6 received an immunosuppressant (methotrexate $(n=4)$, mycophenolate mofetil $(n=2)), 2$ received hydroxychloroquine, and 5 received glucocorticoids (all at a daily dose $\leq 10 \mathrm{mg}$ ), $40 \%$ complained of xerostomia and $36 \%$ of xerophthalmia, Schirmer's test was $\leq 5 \mathrm{~mm}$ in $5 \mathrm{~min}$ in $9 / 17(53 \%)$, and $8 / 17(47.1 \%)$ had an unstimulated salivary flow $\leq 0.1 \mathrm{~mL} /$ minute. The lengths of parotid and submandibular glands were smaller in patients with SSc versus controls after adjustemnt for age and sex $(p=0.02$ and $p=0.04$, respectively). In the SSc group, 7 (28\%) had a salivary gland ultrasound (SGUS) grade $\geq 2(n=5$, grade $3 ; n=2$, grade 4$)$. Five $(71 \%)$ of the 7 patients with SSc with SGUS grade $\geq 2$ were anticentromere antibody (ACA)-positive compared with 4/18 (22\%) patients with SSc with SGUS scores of $0-1(p=0.02)$. None of these seven patients with US abnormalities suggestive of pSS had anti-Ro 60/SSA or La/SSB antibodies.

To date, this is the first study assessing morphological echostructure modifications of the major SGs in patients with SSc. According to our results, more than a quarter of patients with SSc, especially those with ACA, had inhomogeneity of the parotid and submandibular parenchyma that is evocative of pSS. We cannot exclude that the SGUS inhomogeneity is a SSc-related manifestation, especially in patients with SSc with ACA. These observations could more probably represent a distinct ACA-positive SSc/Sjögrenoverlap syndrome, as previously described, that salivary gland ultrasound could identify in a simple and non-invasive way. ${ }^{6}$

\section{Marion Couderc, ${ }^{\oplus 1}$ Anne Tournadre, ${ }^{1}$ Sylvain Mathieu, ${ }^{1}$ Bruno Pereira, ${ }^{2}$ Martin Soubrier, ${ }^{1}$ Jean Jacques Dubost ${ }^{1}$ \\ ${ }^{1}$ Rheumatology, CHU Clermont-Ferrand, Clermont-Ferrand, France ${ }^{2}$ DRCI Biostatistical department, University Hospital, Clermont-Ferrand, France}

Correspondence to Mrs Marion Couderc, Rheumatology, CHU Clermont-Ferrand, Clermont-Ferrand 63000, France; mcouderc@chu-clermontferrand.fr

Contributors MC: conception and design of the work, acquisition, analysis and interpretation of the data, drafting the work, revising and final approval. AT: contribution to the conception and interpretation of the data, revising and 
final approval. SM: contribution to the conception and interpretation of the data, revising and final approval. BP: contribution to the conception, statistical analysis and interpretation of the data, revising and final approval. MS: contribution to the conception and interpretation of the data, revising and final approval. JJD: conception and design of the work, interpretation of the data, drafting the work, revising and final approval.

Funding The authors have not declared a specific grant for this research from any funding agency in the public, commercial or not-for-profit sectors.

Competing interests None declared.

Patient consent for publication Not required.

Ethics approval French CPP nºU1292-07/10/2016, ANSM n²016-A01256-45.

Provenance and peer review Not commissioned; internally peer reviewed.

(C) Author(s) (or their employer(s)) 2019. No commercial re-use. See rights and permissions. Published by BMJ.

\section{A) Check for updates}

To cite Couderc M, Tournadre A, Mathieu S, et al. Ann Rheum Dis Epub ahead of print: [please include Day Month Year]. doi:10.1136/annrheumdis-2019-215777
Received 24 May 2019

Accepted 25 May 2019

Ann Rheum Dis 2019:0:1-2. doi:10.1136/annrheumdis-2019-215777

\section{REFERENCES}

1 Ferdowsi N, Huq M, Stevens W, et al. Development and validation of the scleroderma clinical Trials Consortium damage index (SCTC-DI): a novel instrument to quantify organ damage in systemic sclerosis. Ann Rheum Dis 2019;78:807-16.

2 Kobak S, Oksel F, Aksu K, et al. The frequency of sicca symptoms and Sjögren's syndrome in patients with systemic sclerosis. Int J Rheum Dis 2013;16:88-92.

3 Avouac J, Sordet C, Depinay C, et al. Systemic sclerosis-associated Sjögren's syndrome and relationship to the limited cutaneous subtype: results of a prospective study of sicca syndrome in 133 consecutive patients. Arthritis Rheum 2006;54:2243-9.

4 Avouac J, Airò P, Dieude P, et al. Associated autoimmune diseases in systemic sclerosis define a subset of patients with milder disease: results from 2 large cohorts of European Caucasian patients. J Rheumato/ 2010:37:608-14.

5 Cornec D, Jousse-Joulin S, Pers J-O, et al. Contribution of salivary gland ultrasonography to the diagnosis of Sjögren's syndrome: toward new diagnostic criteria? Arthritis Rheum 2013;65:216-25

6 Baldini C, Mosca M, Della Rossa A, et al. Overlap of ACA-positive systemic sclerosis and Sjögren's syndrome: a distinct clinical entity with mild organ involvement but at high risk of lymphoma. Clin Exp Rheumatol 2013;31:272-80. 